Marquette University

e-Publications@Marquette

School of Dentistry Faculty Research and

Publications

Dentistry, School of

$4-2009$

\title{
Factors Associated With Receipt of Preventive Dental Treatment Procedures Among Adult Patients at a Dental Training School in Wisconsin, 2001-2002
}

\author{
Christopher Okunseri \\ Marquette University \\ Ruta Bajorunaite \\ Marquette University \\ Jessica Mehta \\ Marquette University \\ Brian D. Hodgson \\ Marquette University, brian.hodgson@marquette.edu \\ Anthony lacopino \\ University of Manitoba
}

Follow this and additional works at: https://epublications.marquette.edu/dentistry_fac

Part of the Dentistry Commons

\section{Recommended Citation}

Okunseri, Christopher; Bajorunaite, Ruta; Mehta, Jessica; Hodgson, Brian D.; and lacopino, Anthony, "Factors Associated With Receipt of Preventive Dental Treatment Procedures Among Adult Patients at a Dental Training School in Wisconsin, 2001-2002" (2009). School of Dentistry Faculty Research and Publications. 7.

https://epublications.marquette.edu/dentistry_fac/7 


\title{
Factors Associated With Receipt of Preventive Dental Treatment Procedures among Adult Patients at a Dental Training School in Wisconsin, 2001-2002
}

\author{
Christopher Okunseri \\ Department of Clinical Services, Marquette University School of \\ Dentistry \\ Milwaukee, WI \\ Ruta Bajorunaite \\ Department of Mathematics, Statistics and Computer Science, \\ Marquette University \\ Milwaukee, WI \\ Jessica Mehta \\ Department of Clinical Services, Marquette University School of \\ Dentistry \\ Milwaukee, WI \\ Brian Hodgson \\ Department of Developmental Sciences, Marquette University \\ School of Dentistry \\ Milwaukee, WI \\ Anthony M. Iacopino \\ Department of Restorative Dentistry, University of Manitoba \\ Winnipeg, Manitoba, Canada
}

Gender Medicine, Vol. 6, No. 1 (April 2009): pg. 272-276. DOI. This article is (C) Elsevier and permission has been granted for this version to appear in e-Publications@Marquette. Elsevier does not grant permission for this article to be further copied/distributed or hosted elsewhere without the express permission from Elsevier. 
NOT THE PUBLISHED VERSION; this is the author's final, peer-reviewed manuscript. The published version may be accessed by following the link in the citation at the bottom of the page.

\begin{abstract}
:
Background: Gender differences in oral health-related quality of life and the fear of dental pain in seeking and receiving preventive dental care have been recognized and documented. Preventive dental treatment procedures (PDTPs) are commonly accepted as the primary approach to prevent dental disease. Objective: We examined whether the likelihood of receiving PDTPs differed by gender in adult patients receiving dental care at a dental training institution in Milwaukee, Wisconsin. Methods: Data from the Marquette University School of Dentistry electronic patient management database for 2001 through 2002 were analyzed. Descriptive, bivariate, and multivariable analyses were performed. The preventive procedures used in the study were those coded in accordance with the American Dental Association's classification system: D1110 (adult prophylaxis: professional cleaning and polishing of the teeth), D1204 (adult topical application of fluoride), D1205 (adult topical application of fluoride plus prophylaxis), and D1330 (oral hygiene instruction). Results: Of the 1563 consecutive patient records (888 women, 675 men) reviewed for the years 2001-2002, 794 individuals (51\%), aged 18 to 60 years, were identified as having received PDTPs. At the bivariate level, a significant gender difference in the receipt of PDTPs was identified (423 women [48\%] vs 371 men [55\%]; P = 0.004). In the multivariable analyses, age, race/ethnicity, marital status, poverty level, and health insurance type (public, private, none) were significantly associated with the receipt of PDTPs (all, P $<0.05$ ), but gender was not. Conclusions: Gender differences in receiving PDTPs were not found in this dental school patient population. Receipt of PDTPs was associated with other demographic factors such as age, race/ethnicity, marital status, income level, and health insurance.
\end{abstract}

\title{
Introduction
}

Gender differences in oral health-related quality of life, dental health behavior, fear of dental pain, and preventive dental visits have all been recognized and documented..$^{1-5}$ Gender differences in dental disease burden, access to care, and how women and men react to disease prevention and health promotion activities have also been described. ${ }^{6,7}$ However, little attention has been paid to the relationship between the health care system and individual-level factors that influence gender differences in the receipt of preventive dental treatment procedures (PDTPs), Desvarieux et $\mathrm{al}^{8}$ found gender differences in cardiovascular morbidity or mortality, based on the contribution of novel risk factors across gender following the examination of the relationship between periodontal disease, tooth loss, and atherosclerosis. The study reported that atherosclerosis was associated with clinical attachment loss and tooth loss in males but not in females. Furthermore, a higher percentage of males had periodontal depth $\geq 5 \mathrm{~mm}$.

Gender Medicine, Vol. 6, No. 1 (April 2009): pg. 272-276. DOI. This article is (C) Elsevier and permission has been granted for this version to appear in e-Publications@Marquette. Elsevier does not grant permission for this article to be further copied/distributed or hosted elsewhere without the express permission from Elsevier. 
Studies have noted that the most likely users of dental services are female, white, college-educated urban dwellers who earn high salaries, have dental insurance, and are in good general health. 9 It is well known that compared with men, women seek more care for acute and chronic conditions and access health services more frequently.10 To our knowledge, very little has been reported on whether females are more likely to be provided with PDTPs than are males. With females being the most likely users of dental care, one might expect them to have a higher probability of receiving PDTPs to prevent the occurrence of the 2 most common dental diseases, dental caries and periodontal disease, which are also chronic conditions.

Preventive dental visits are essential to establishing and maintaining good oral health. ${ }^{1}$ The receipt and utilization of PDTPs also promote and maintain good oral health-related quality of life. In addition, preventive dental interventions are effective in reducing the incidence of dental caries and their associated expense. ${ }^{11}$ Studies have documented that gender is a determinant of dental services utilization and that differences exist in dental visit patterns. ${ }^{12,13}$ However, the use of PDTPs, which is different from self-reported dental visits and preventive dental visits, has received limited attention. In particular, little is known about whether women and men are equally likely to receive PDTPs. Our study objective, therefore, was to examine whether there is a gender difference in the likelihood of receiving PDTPs among adult patients under dental care at a dental training institution.

\section{Methods}

We analyzed administrative data from the electronic patient management database at Marquette University School of Dentistry in Milwaukee, Wisconsin, for the years 2001 through 2002. The study included all consecutive active adult patient records (ie, patients who were seen for comprehensive care, not emergency walk-ins) at the dental school. The database contained information on patient age, gender, race/ethnicity, marital status, poverty level, and health insurance type. In our analyses, insurance status was defined as private/commercial, public (Medicaid and/or Medicare), out of pocket (patients who were uninsured and/or paying for treatment out of pocket), and unknown, Income was categorized as either below or above poverty level, based on US Census Bureau classification. ${ }^{14}$ Other information available included the different types of PDTPs provided to patients, coded in accordance with the American Dental Association's procedure classification. The following PDTP codes were included in our study: D1110 (adult prophylaxis: professional cleaning and polishing

Gender Medicine, Vol. 6, No. 1 (April 2009): pg. 272-276. DOI. This article is (C Elsevier and permission has been granted for this version to appear in e-Publications@Marquette. Elsevier does not grant permission for this article to be further copied/distributed or hosted elsewhere without the express permission from Elsevier. 
of the teeth), D1204 (adult topical application of fluoride), D1205 (adult topical application of fluoride plus prophylaxis), and D1330 (oral hygiene instruction).

\section{Statistical Analysis}

Because the focus of the present study was on gender differences, the analysis was limited to those patients who provided complete information that included gender. To determine significant differences between subgroups of the study population, $x 2$ testing was employed. Information on age was used as a continuous variable in all analyses. A logistic regression model was used to model the probability of receiving PDTPs while adjusting for other covariates such as age, race/ethnicity, marital status, income, and health insurance. A statistical goodness-of-fit test was employed to assess the appropriateness of our final model. All statistical analyses were performed using SAS version 9.1 software (SAS Institute Inc., Cary, North Carolina). Statistical significance was set at $a=0.05$, and all tests were 2-tailed.

\section{Results}

Overall, 1574 adult patients were seen at the clinic from 2001 through 2002. Of these patients, complete database information was available for 1563 patients for the final analysis. Fifty-seven percent of the patients seen at the clinic were women. White patients comprised $50 \%$ of the study population, blacks $22 \%$, Hispanics $6(\%)$, others $5 \%$, and unknown $17 \%$. Individuals with public health insurance, those paying out of pocket, and those who had private insurance accounted for $45 \%, 32 \%$, and $23 \%$ of all patients, respectively. In both years, approximately half of the patients seen at the clinic had incomes below the poverty level.

The results of a bivariate analysis for factors associated with rates of receipt of PDTPs are shown in Table I. Fifty-one percent of the patients, $48 \%$ of women, $60 \%$ of whites, and $53 \%$ of public insurance holders received PDTPs. A significant gender difference was evident between the women and men who received PDTPs (48\% vs 55\%, respectively; $P=0.004)$. White patients were more likely to have PDTPs compared with Hispanics (45\%) and blacks (41\%) during the study period. In addition, age and income level were significant factors affecting receipt of $P$ OTPS.

Table II presents results of the logistic regression model on the probability of receiving PDTPs while adjusting for age, race/ethnicity,

Gender Medicine, Vol. 6, No. 1 (April 2009): pg. 272-276. DOI. This article is (C Elsevier and permission has been granted for this version to appear in e-Publications@Marquette. Elsevier does not grant permission for this article to be further copied/distributed or hosted elsewhere without the express permission from Elsevier. 
marital status, poverty level, and health insurance. After adjusting for these covariates, gender was not a significant predictor of receiving PDTPs, although women had numerically lower odds of receiving PDTPs than did men (adjusted odds ratio [AOR] $=0.83 ; 95 \% \mathrm{CI}, 0.67-$ 1.03). Age was significantly associated with the receipt of PDTPs $(P<$ $0.001)$; the odds of receiving PDTPs significantly rose with every additional year of age $(A O R=1.03 ; 95 \% C I, 1.02-1.04)$. Compared with whites, blacks had lower odds of receiving PDTPs (AOR $=0.44$; 95\% CI, 0.33-0.58), whereas Hispanics were not statistically different from whites $(A O R=0.70 ; 95 \% C I, 0.44-1.10)$. Patients with incomes above the poverty level were significantly more likely to receive PDTPs compared with patients who had incomes below the poverty level $(A O R=1.36 ; 95 \% C I, 1.01-1.83]$. For individuals who paid out of pocket, the adjusted odds of receiving PDTPs were significantly lower compared with individuals who were covered by public health insurance $(A O R=0.65 ; 95 \% C I, 0.50-0.84)$.

We also adjusted for the possibility of a correlation between patients who could visit in both years; however, we found similar results.

\section{Discussion}

In the present study, $\sim 1$ of every 2 active patients undergoing dental care at the study facility received PDTPs. Women were significantly less likely to receive PDTPs; however, the difference between women and men was not significant after adjusting for covariates. It is difficult to directly compare our findings with those of others who have reported on regular and preventive dental visits, frequency of dental checkups, and use of dental services and providers, because most studies have analyzed data from a national database, ${ }^{11,15,16}$ whereas ours used actual patient records from a dental training facility. Moreover, the information from the national database was self-reported, and no effort was made to verify it with patient records.

After adjustment for other covariates, race/ethnicity was significantly associated with receipt of PDTPs. Blacks were less likely than whites to receive PDTPs, a finding congruent with what is generally reported in most dental health services research. ${ }^{1,15,16}$ In the present study, Hispanics were found to be numerically less likely than whites to receive PDTPs, but the difference between the 2 groups was not statistically significant. Older age was significantly associated with an increase in the probability of receiving PDTPs. However, the reason why older patients appear to receive more PDTPs requires further

Gender Medicine, Vol. 6, No. 1 (April 2009): pg. 272-276. DOI. This article is (C) Elsevier and permission has been granted for this version to appear in e-Publications@Marquette. Elsevier does not grant permission for this article to be further copied/distributed or hosted elsewhere without the express permission from Elsevier 
investigation from other databases in which diagnostic codes are available to serve as a covariate in the study.

To apply the findings from the present study, dental health professionals should continue to educate all patients, reinforcing the need for PDTPs in addition to addressing their primary complaints. Dental health professionals should also educate their patients and the community about the benefits of preventive therapy regardless of gender, race/ethnicity, income, or the level of dental disease burden. This supports a comprehensive, whole-population approach to dental care and the concept of a dental "home" for all patients.

Certain strengths and limitations of our data should be noted. One limitation of this study is that a single institution's database was used, and thus these results cannot be generalized beyond the studied sample. Nonetheless, the data set included specific PDTPs and relevant demographic and income information. Another limitation is that the analyses did not adjust for potential confounders such as the number of teeth, oral health status, the patient's dental disease burden or disease diagnosis, status as a recall patient, or the number of years the patient was seen at the dental school. We also recognize that most people receive their dental care from private dental practices, and that findings from those settings could be different. This study's findings have important implications for dental health care provision for any setting that seeks to provide equitable care regardless of gender or race. Studies in other settings, especially private practice, are required to determine if gender differences actually exist, given what we know about self-reported preventive dental visits and the most likely users of dental services.

\section{Conclusions}

Among those receiving care in this dental training institution, no significant gender difference was observed in the receipt of PDTPs. Other factors such as age, race/ethnicity, marital status, income, and health insurance were associated with the receipt of PDTPs.

\section{References}

1. Goodman HS, Manski MC, Williams JN, Manski RJ. An analysis of preventive dental visits by provider type, 1996. J Am Dent Assoc. 2005;136:221228.

Gender Medicine, Vol. 6, No. 1 (April 2009): pg. 272-276. DOI. This article is (C) Elsevier and permission has been granted for this version to appear in e-Publications@Marquette. Elsevier does not grant permission for this article to be further copied/distributed or hosted elsewhere without the express permission from Elsevier. 
2. Skaret E, Raadal M, Kvale G, Berg E. Gender-based differences in factors related to non-utilization of dental care in young Norwegians. A longitudinal study. Eur J Oral Sci. 2003;111:377-382.

3. McGrath C, Bedi R. Gender variations in the social impact of oral health. .J Ir Dent Assoc. 2000;46:87-91.

4. Heft MW, Meng X, Bradley MM, Lang PJ. Gender differences in reported dental fear and fear of dental pain. Community Dent Oral Epidemiol. $2007 ; 35: 421-428$.

5. Sakki TK, Knuuttila ML, Anttila SS. Lifestyle, gender and occupational status as determinants of dental health behavior. $J$ Clin Periodontol.1998;25:566-570.

6. Zakrzewska JM. Women as dental patients: Are there any gender differences? Int Dent J.1996; 46:548-557.

7. Gift HC, Gerbert B, Kress GC, Reisine ST. Social, economic and professional dimensions of the oral health care delivery systems. Ann Behav Med. $1990 ; 12: 161-169$.

8. Desvarieux M, Schwahn C, Völzke H, et al. Gender differences in the relationship between periodontal disease, tooth loss, and atherosclerosis. Stroke. 2004;35:2029-2035.

9. Brian BA, Eklund SA. Dentistry, Dental Practice, and the Community. 6th ed. St. Louis, Mo: Elsevier Saunders; 2005.

10. Verbrugge LM. Pathways of health and death. In: Apple RD, ed. Women, Health and Medicine in America. New York, NY: Garland Science; 1990.

11. Savage MF, Lee JY, Kotch JB, Vann WF Jr. Early preventive dental visits: Effects on subsequent utilization and cost. Pediatrics. 2004;114:e416e423.

12. Davenport C, Elley K, Salas C, et al. The clinical effectiveness and costeffectiveness of routine dental checks: A systematic review and economic evaluation. Health Technol Assess. 2003; 7:iii-v, 1-127.

13. Petersen PE, Holst D. Utilization of dental health services. In: Cohen LE, Gift H, eds. Disease Prevention and Oral Health Promotion: SocioDental Sciences in Action. New York, NY, and Copenhagen, Denmark: Munksgaard; 1995:341-386.

14. United States Census Bureau. Poverty thresholds. http://www.census.gov/hhes/www/poverty/threshld.html. Accessed June 20, 2008.

15. Woolfolk MW, Lang WP, Borgnakke WS, et al. Determining dental checkup frequency. J Am Dent Assoc. 1999;130:715-723.

16. Hayward RA, Meetz HK, Shapiro MF, Freeman HE. Utilization of dental services: 1986 Patterns and trends. J Public Health Dent. 1989;49:147-152.

Gender Medicine, Vol. 6, No. 1 (April 2009): pg. 272-276. DOI. This article is (C) Elsevier and permission has been granted for this version to appear in e-Publications@Marquette. Elsevier does not grant permission for this article to be further copied/distributed or hosted elsewhere without the express permission from Elsevier. 


\section{Appendix}

Table I: Bivariate analysis of factors associated with dental patients' receipt of preventive dental treatment procedures (PDTPs). Unless otherwise indicated, data are no. (\%) of patients

\begin{tabular}{|c|c|c|}
\hline Variable & Rate of Receiving PDTPs & $\rho$ \\
\hline Patients & $794 / 1563(51)$ & \\
\hline $\begin{array}{l}\text { Gender } \\
\text { remale } \\
\text { Male }\end{array}$ & $\begin{array}{l}423 / 888(48) \\
371 / 675(55)\end{array}$ & 0.004 \\
\hline Median age (range), y & $43(18-60)$ & 0.003 \\
\hline $\begin{array}{l}\text { Race/ethnicity } \\
\text { White } \\
\text { Black } \\
\text { Hispanic } \\
\text { Other } \\
\text { Unknown }\end{array}$ & $\begin{array}{r}470 / 779(60) \\
140 / 343(41) \\
43 / 95(45) \\
33 / 75(44) \\
108 / 271(40)\end{array}$ & $<0.001$ \\
\hline $\begin{array}{l}\text { Marital status } \\
\text { Single } \\
\text { Married } \\
\text { Divorced, widowed } \\
\text { Unknown }\end{array}$ & $\begin{array}{r}393 / 765(51) \\
215 / 399(54) \\
112 / 234(48) \\
74 / 165(45)\end{array}$ & 0.190 \\
\hline $\begin{array}{l}\text { Poverty level } \\
\text { Above } \\
\text { Below } \\
\text { Unknown }\end{array}$ & $\begin{array}{l}185 / 313(59) \\
368 / 791(47) \\
241 / 459(53)\end{array}$ & $<0.001$ \\
\hline $\begin{array}{l}\text { Health insurance } \\
\text { Public } \\
\text { Private } \\
\text { Out of pocket } \\
\text { Unknown }\end{array}$ & $\begin{array}{r}368 / 700(53) \\
62 / 113(55) \\
252 / 504(50) \\
112 / 246(46)\end{array}$ & 0.213 \\
\hline
\end{tabular}


NOT THE PUBLISHED VERSION; this is the author's final, peer-reviewed manuscript. The published version may be accessed by following the link in the citation at the bottom of the page.

\section{Table II: Multivariable analyses of factors associated with dental patients' receipt of preventive dental treatment procedures (PDTPs).}

\begin{tabular}{|c|c|c|}
\hline Variable & $\begin{array}{l}\text { AOR }(95 \% \mathrm{Cl}) \text { of Rate } \\
\text { of Receiving PDTPs }\end{array}$ & P \\
\hline $\begin{array}{l}\text { Gender (Referent: male) } \\
\text { Female }\end{array}$ & $0.83(0,67-1.03)$ & 0.085 \\
\hline Age & $1.03(1.02-1.04)$ & $<0.001$ \\
\hline $\begin{array}{l}\text { Race/ethnicity } \\
\text { (Referent: white) } \\
\text { Black } \\
\text { Hispanic. } \\
\text { Other } \\
\text { Unknown }\end{array}$ & $\begin{array}{l}0.44(0.33-0.58) \\
0.70(0.44-1.10) \\
0.57(0.35-0.93) \\
0.41(0.29-0.59)\end{array}$ & $<0.001$ \\
\hline $\begin{array}{l}\text { Marital status } \\
\text { (Referent: married) } \\
\text { Single } \\
\text { Divorced, widowed } \\
\text { Unknown }\end{array}$ & $\begin{array}{l}1.24(0.94-1.64) \\
0.73(0.52-1.03) \\
1.04(0.68-1.59)\end{array}$ & 0.015 \\
\hline $\begin{array}{l}\text { Poverty level } \\
\text { (Referent: below } \\
\text { poverty level) } \\
\text { Above } \\
\text { Unknown }\end{array}$ & $\begin{array}{l}1.36(1.01-1.83) \\
1.34(1.02-1.76)\end{array}$ & 0.034 \\
\hline $\begin{array}{l}\text { Health Insurance } \\
\text { (Referent: public) } \\
\text { Private } \\
\text { Out of pocket } \\
\text { Uriknown }\end{array}$ & $\begin{array}{l}0.65(0.42-1.02) \\
0.65(0.50-0.84) \\
0.55(0.40-0.75)\end{array}$ & $<0.001$ \\
\hline
\end{tabular}

$\mathrm{AOR}=$ adjusted odds ratio. 